\title{
Dicer Regulates the Expression of Major Histocompatibility Complex (MHC) Class I Chain-Related Genes A and B
}

\author{
Kai-Fu Tang \\ Wenzhou Medical College \\ China
}

\section{Introduction}

RNAi constitutes a key component of the innate immune response to viral infection in both plants and invertebrate animals, and has been postulated to function as the genome or intracellular immune system (Fire A., 2005; Plasterk RH., 2002; Umbach JL. \& Cullen BR., 2009). Knockdown of Dicer, the key component of the RNAi pathway, elicits DNA damage and induces the expression of MHC class I chain-related gene A and B (MICA and MICB), two ligands of the NKG2D receptor expressed by natural killer cells and activated CD8 ${ }^{+} \mathrm{T}$ cells (Tang KF. et al, 2008b). In this chapter, I discuss the possible molecular mechanisms by which decreased Dicer expression elicits DNA damage and induces the expression of MICA and MICB. MICA and MICB are frequently up-regulated in epithelial tumors of diverse tissue origins (Gasser S. \& Raulet DH., 2006). Dicer is down-regulated in most tumor tissues (Merritt WM. et al, 2008; Wu JF. et al, 2011), and DNA damage response is activated in human tumors and precancerous lesions (Bartkova J. et al, 2005, 2006; DiTullio RA Jr. et al, 2002; Gorgoulis VG. et al, 2005). Therefore, the possible roles of Dicer, DNA damage, and MICA and MICB in tumorigenesis are also discussed.

\section{RNA interference and the intracellular immune system}

Experimental introduction of antisense RNA into cells was once used to interfere with the function of endogenous genes (Izant JG. \& Weintraub H., 1984; Nellen W. \& Lichtenstein C., 1993). However, Fire and colleagues found in 1991 that plasmid-encoded sense RNA is sufficient to cause interference (Fire A. et al, 1991); Guo and Kemphues reported in 1993 that, in addition to antisense RNA, sense RNA and double-stranded RNA (dsRNA) interfere with the function of endogenous genes (Guo S. \& Kemphues KJ., 1995). In 1998, Fire and colleagues found that double-stranded RNA is substantially more effective at producing interference than either strand individually (Fire A. et al, 1998). After injection into adult animals, purified single strands had at most a modest effect, whereas doublestranded mixtures caused potent and specific interference (Fire A. et al, 1998). This phenomenon is now termed RNA interference (RNAi). Historically, RNAi was also known as other names, including posttranscriptional gene silencing (PTGS) and cosuppression in plants (Napoli C. et al, 1990; van der Krol AR. et al, 1990), RNA-mediated 
virus resistance in plants (Lindbo JA. \& Dougherty WG., 1992), and"quelling" in Neurospora (Cogoni C., 1996) and algae (Wu-Scharf D. et al, 2000). It was postulated that the main functions of the RNAi pathway include antiviral defense, heterochromatic silencing, and transposon regulation (Martienssen RA. et al, 2008; Umbach JL. \& Cullen BR., 2009). Therefore, Plasterk and Fire proposed that RNAi is the genome or intracellular immune system (Fire A., 2005; Plasterk RH., 2002).

\section{Dicer is the key component of the RNAi pathway}

RNAi is characterized by the presence of RNAs of about 22 nucleotides in length that are homologous to the gene being suppressed (Hamilton AJ. \& Baulcombe DC., 1999; Hammond SM. et al, 2000; Zamore PD. et al, 2000). These 22-nucleotide sequences, called short interfering RNAs (siRNAs), serve as guide sequences that instruct a multicomponent nuclease, RNA-Induced Silencing Complex (RISC), to destroy the homologous messenger RNAs (Hammond SM. et al, 2000). Dicer, the key component of the RNAi pathway, was identified by Bernstein and colleagues (Bernstein E. et al, 2001). They demonstrated that immunoprecipitated Dicer can generate 22-nucleotide RNAs from dsRNA substrates, and that inhibition of Dicer expression significantly reduces processing of long dsRNA in wholecell lysates or in Dicer immunoprecipitates (Bernstein E.et al, 2001). In addition to the extrogenous siRNAs, Dicer is also responsible for the biogenesis of endogenous siRNAs. In Schizosaccharomyces pombe, Dicer processes endogenous dsRNA derived from centromeric repeats. The small RNAs are then associated with Ago1, Chp1, and Tas3 to form the RNA-induced initiation of transcriptional gene silencing (RITS) complex that is required for heterochromatin assembly in fission yeast (Verdel A. et al, 2004). Deletion of Dicer results in the aberrant accumulation of complementary transcripts from centromeric heterochromatic repeats. This is accompanied by transcriptional de-repression of transgenes integrated at the centromere, loss of histone H3 lysine- 9 methylation, and impaired centromere function (Volpe TA. et al, 2002). The Drosophila endogenous siRNAs are derived from transposons, heterochromatic sequences, and stem-loop structures containing RNAs. Normal accumulation of these endogenous siRNAs requires the siRNA-generating ribonuclease, Dicer, and the RNA interference effector protein, Ago2; mutations in Dicer causes an increase in these transcripts (Czech B. et al, 2008; Ghildiyal M. et al, 2008; Kawamura Y. et al, 2008; Okamura K. et al, 2008). SiRNAs are target-dependent amplified in some organisms. DsRNA is cut into siRNAs, the double-stranded siRNAs are converted into single-stranded siRNAs by the slicer activity of Ago2, the sense strands are degraded, and the antisense strands anneal to their targets and induce target degradation. Alternatively, the antisense RNAs may serve as primers, inducing dsRNA synthesis by the RNAdependent RNA polymerase (RdRP); Dicer then cuts the dsRNAs to generate secondary siRNAs (Plasterk RH., 2002). Whether there are endogenous siRNAs in organisms lacking RdRP activity was investigated by means of deep sequencing. Two groups found that endogenous siRNAs derived from pseudogenes, natural antisense transcripts, and transposable elements exist in mouse oocytes (Tam OH. et al, 2008; Watanabe T. et al, 2008).

In addition to producing siRNA, Dicer is also required for the biogenesis of other types of small RNAs. Hutvagner and colleagues presented evidence that in Drosophila, a developmentally regulated microRNA (miRNA) precursor, pre-let-7, is cleaved by an RNA 
interference-like mechanism to produce mature let-7 miRNA (Hutvágner G. et al, 2001). In cultured human cells, knockdown of Dicer leads to accumulation of the let-7 precursor. This is the first evidence that the RNA interference and miRNA pathways intersect (Hutvágner G. et al, 2001). In addition to the biogenesis of siRNAs and miRNAs, Dicer is also required for the degradation of unstable RNAs containing AU-rich elements (AREs) in 3-prime untranslated regions (UTRs) (Jing Q. et al, 2005). Morever, Dicer also functions in fragmenting chromosomal DNA during apoptosis. Nakagawa and colleagues reported that inactivation of the Caenorhabditis elegans Dicer gene compromises apoptosis and blocks apoptotic chromosome fragmentation (Nakagawa A. et al, 2010). Dicer is cleaved by the Ced3 caspase to generate a C-terminal fragment with deoxyribonuclease activity, which produces 3-prime hydroxyl DNA breaks on chromosomes and promotes apoptosis (Nakagawa A. et al, 2010).

\section{Dicer is essential for heterochromatin formation}

Depletion of Dicer disrupts heterochromatin formation in Schizosaccharomyces pombe, Arabidopsis thaliana, Caenorhabditis elegans, Tetrahymena thermophila, and Drosophila melanogaster (Grewal SI., 2010; Lejeune E. \& Allshire RC., 2011; Martienssen RA. et al, 2008; Riddle NC. \& Elgin SC., 2008). However, whether Dicer is involved in heterochromatin formation in mammalian cells is still controversial. Kanellopoulou and colleagues reported that knockout of Dicer in mouse ES cells disrupts centromeric heterochromatin formation, with reduced histone $\mathrm{H} 3 \mathrm{~K} 9$ di-methylation and tri-methylation, reduced DNA methylation, and increased levels of centromeric repeat RNAs. The decondensation of heterochromatin is accompanied by markedly reduced levels of the 25-30 nt centromeric small dsRNAs, suggesting that Dicer-dependant small RNAs are required for the formation of centromeric heterochromatin (Kanellopoulou C. et al, 2005). Two groups found that the retinoblastomalike 2 protein (Rbl2) is the target of miR-290 family miRNAs, and that Rbl2 can inhibit the expression of DNA methyltransferases (Dnmts), including Dnmt1, Dnmt3a and Dnmt3b (Benetti R. et al, 2008; Sinkkonen L. et al, 2008). Dicer deficiency in mice leads to decreased DNA methylation. DNA-methylation defects correlate with decreased expression of Dnmts and miR-290 family miRNAs, and can be reversed by transfection with miR-290 family miRNAs. These results indicate that the DNA hypomethylation in Dicer knockout cells is the consequence of low levels of miR-290 family miRNAs (Benetti R. et al, 2008; Sinkkonen L. et al, 2008). However, Benetti and colleagues found that Dicer is not required for histone tri-methylation. They observed that Dicer-null cells have a normal density of H3K9me3 and H4K20me3 marks and of HP1-binding at pericentric repeats, and that these heterochromatic histone marks are significantly increased at telomeric chromatin in Dicer-null cells compared to wild-type controls. They also found that the active chromatin mark, AcH3K9, is decreased at Dicer-null telomeres compared to wild-type telomeres, and that the density of this mark was not significantly decreased at pericentric chromatin. These results suggest that Dicer knockout cells have a higher degree of chromatin compaction and silencing at telomeric chromatin (Benetti R. et al, 2008). Hannon's group reported that although loss of Dicer affects the abundance of transcripts from centromeres in mouse ES cells, the histone modification status at pericentric repeats and methylation of centromeric DNA are not affected in Dicer knockout ES cells (Murchison EP. et al, 2005). Cobb and colleagues reported that the maintenance of constitutive and facultative heterochromatin seemed to be unperturbed in Dicer knockout thymocytes (Cobb BS. et al, 2005). 


\section{Decreased Dicer expression elicits DNA damage}

The timing of DNA replication is tightly regulated and correlates with chromatin state. Highly condensed heterochromatin replicates late in S phase, while less condensed euchromatin tends to replicate early (Donaldson AD., 2005). Although the replication times of many single copy loci, including a $5 \mathrm{Mb}$ contiguous region surrounding the Rex 1 gene, are unchanged in Dicer mutant ES cells, the temporal control of satellite DNA replication is sensitive to loss of Dicer (Jørgensen HF. et al, 2007). Misregulation of the timing of DNA replication may cause stalled and collapsed replication forks, which in turn elicit a DNA damage response (Sancar A. et al, 2004). Loss of Dicer in Drosophila cells not only results in decondensation of heterochromatin but also leads to accumulation of extrachromosomal circular (ecc) repeated DNAs. Ligase IV, an essential regulator of nonhomologous endjoining and perhaps other DNA damage-repair machinery, participates in eccDNA formation (Peng JC. \& Karpen GH., 2007). This suggests that, while heterochromatin decondensation increases the access of DNA repair and recombination proteins to repeated DNA, activation of DNA damage response may also contribute to the formation of eccDNA in Dicer mutant cells. RNAi is postulated to function as the genome's immune system, defending against molecular parasites such as transposons and viruses, and loss of Dicer may activate transposition (Fire A., 2005; Plasterk RH., 2002). Transposition generates double strand DNA breaks and elicits a DNA damage response (Gasior SL. et al, 2006). Chromatin structure is essential for maintaining genome integrity (Peng JC. \& Karpen GH., 2008). For example, Drosophila cells that lack the Su(var)3-9 H3K9 methyltransferase have significantly elevated frequencies of spontaneous DNA damage in heterochromatin. Accumulated DNA damage in these mutants correlates with chromosomal defects, such as translocations and loss of heterozygosity. Based on the observation that S-phase in Su(var)39 mutants is significantly shorter than that in wild type cells, the authors proposed that accumulation of DNA damage in Su(var)3-9 mutants is the consequence of defective DNA replication (Peng JC. \& Karpen GH., 2009). The regions of repetitive DNA may be incompletely replicated or defective in chromatin reassembly because of a shortened $S$ phase. Alternatively, repeated DNA in heterochromatin may undergo faster replication, resulting in more replication errors. However, the demonstration that DNA damage is detected in G1, S, and G2 stages in Su(var)3-9 mutants suggests that defective DNA replication is not the only cause of the increased DNA damage. HP1 $\beta$, whose localization requires $\mathrm{H} 3 \mathrm{~K} 9 \mathrm{me}$, is needed for efficient DNA damage detection in mammalian cells (Ayoub et al, 2008). Therefore, another explanation for the increased frequencies of DNA damage in Su(var)3-9 mutant cells may be that proper DNA damage detection and subsequent DNA repair response are impaired (Peng JC. \& Karpen GH., 2009). We also demonstrated that 5-Aza-2'-deoxycytidine (5-aza-dC), a DNA methyltransferase inhibitor, induces DNA damage in human cells (Tang KF. et al, 2008a).

To test whether loss of Dicer can induce DNA damage, we knocked down Dicer in HEK293T cells and human hepatoma HepG2 cells and measured markers for DNA damage. Immunostaining assays for the phosphorylated form of histone $\mathrm{H} 2 \mathrm{AX}(\gamma-\mathrm{H} 2 \mathrm{AX})$, a widely used marker for double-strand DNA breaks (Foster ER. \& Downs JA., 2005), and for the replication protein A 70 (RPA70), a protein that becomes phosphorylated and forms intranuclear foci upon exposure of cells to DNA damage (Zou Y. et al, 2006), revealed that a much higher percentage of Dicer knockdown cells display intense $\gamma-\mathrm{H} 2 \mathrm{AX}$ foci and RPA foci compared to control cells (Tang KF. et al, 2008b). Using a comet assay to directly assess DNA 
damage, we confirmed that knockdown of Dicer resulted in accumulation of DNA breaks (Tang KF. et al, 2008b). Consistent with our results, Peng and Karpen reported a significant increase in spontaneous DNA damage in heterochromatic DNAs of Dicer mutant Drosophila cells (Peng JC. \& Karpen GH., 2009). Mudhasani and colleagues reported that loss of Dicer activates a DNA damage checkpoint, up-regulates p19(Arf)-p53 signaling, and induces senescence in primary cells (Mudhasani R. et al, 2008).

In Figure 1, I summarize the possible mechanisms on how loss of Dicer leads to DNA damage. First, loss of Dicer reduces the level of endogenous siRNAs, resulting in heterochromatin decondensation. Heterochromatin decondensation may induce DNA damage via the following mechanisms: (i) loss of H3K9 methylation compromises DNA damage detection and subsequent DNA repair response, leading to DNA damage accumulation; (ii) disruption of DNA replication timing induces DNA damage; and (iii) mobilization of transposon and retrotransposon creates DNA double-strand breaks. Second, loss of Dicer stabilizes dsRNA derived from transposons and retrotransposons, causing a high level of transposition and generating DNA double-strand breaks. Third, loss of Dicer compromises miRNA biogenesis. Some miRNAs, such as the miR290 family, can suppress the expression of DNA methyltransferases or histone modifiers; loss of such miRNAs may cause heterochromatin decondensation, which in turn results in DNA damage. Loss of miRNAs that target to components of the DNA damage repair pathway may cause insufficient DNA damage repair, leading to DNA damage accumulation. These molecular events may act synergically or additively in Dicer mutant cells to induce DNA damage.

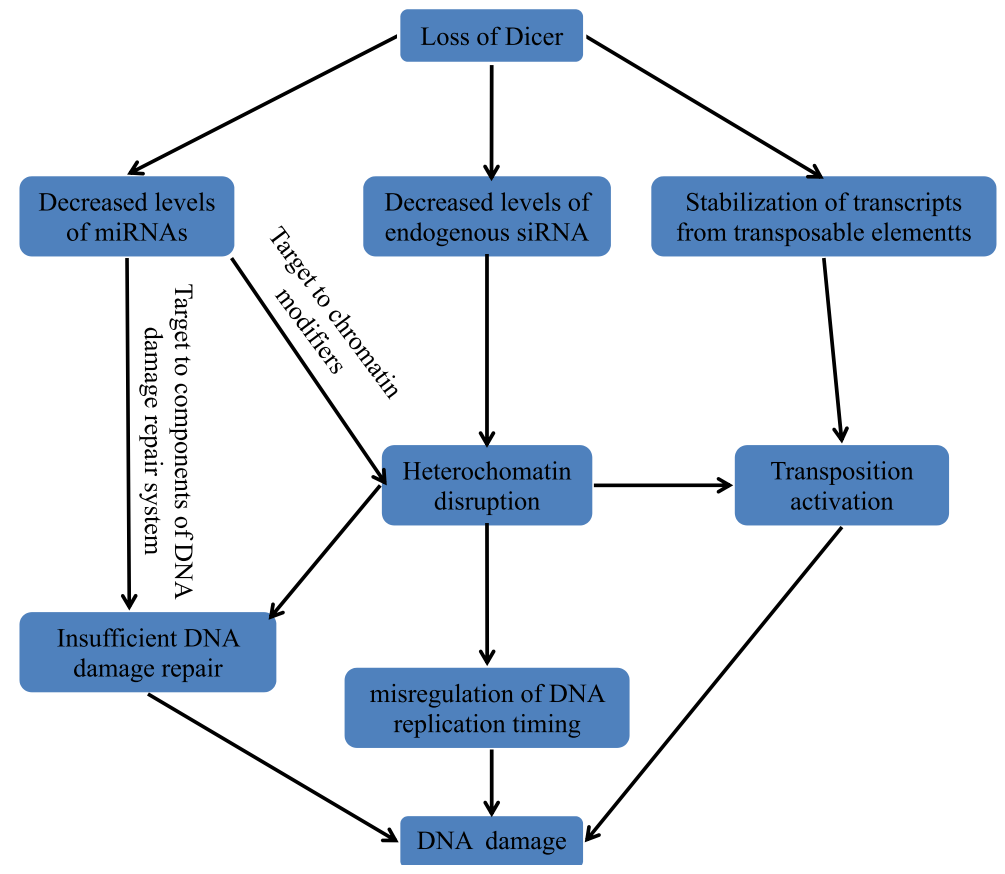

Fig. 1. Molecular mechanisms of DNA damage arising from decreased Dicer expression. 


\section{DNA damage response induces the expression of ligands for the NKG2D receptor}

Natural killer (NK) cells, components of the innate immune system, can kill certain transformed or virus-infected cells lacking MHC class I, yet spare the cells expressing MHC class I. The ability to attack cells missing 'self' markers predicted the existence of both inhibitory and activating receptors on NK cells (Lanier LL., 2008). Unlike T and B cells, which possess a single antigen receptor that dominates cellular development and activation, NK cells do not possess one dominant receptor, but instead have a vast array of receptors to initiate effector functions. None of the receptors alone, with the exception of CD16, is able to elicit cytolytic activity or cytokine secretion (Lanier LL., 2008). The NKG2D receptor complex is one of the activating NK receptors. It is a hexamer, with one NKG2D homodimer associated with two DAP10 homodimers. A single gene encodes NKG2D, which is a C-type lectin-like superfamily member, and a type II transmembrane-anchored glycoprotein expressed as a disulfide-bonded homodimer on the surface of NK cells, $\gamma \delta$ T cells, and CD8+ T cells (Lanier LL., 2008). Engagement of NKG2D by its ligands leads either to the direct activation of killing and cytokine secretion by NK cells or to a costimulation of cytotoxic Tlymphocyte cytotoxicity (Lanier LL., 2008; Stern-Ginossar N. \& Mandelboim O., 2009). In humans, NKG2D ligands are divided into two families: the MHC class I polypeptide-related chain (MIC) protein family, which contains MICA and MICB; and the cytomegalovirus UL16-binding proteins (ULBP) family, which consists of five members (ULBP1, ULBP2, ULBP3, ULBP4, and REAT1G) (Stern-Ginossar N. \& Mandelboim O., 2009).

Gasser and colleagues found that NKG2D ligands are up-regulated in non-tumor cell lines by genotoxic stress and stalled DNA replication, conditions known to activate a major DNA damage checkpoint pathway (Gasser S. et al, 2005). The DNA damage checkpoints employ damage sensor proteins, such as ATM, ATR, the Rad17-RFC complex, and the 9-1-1 complex, to detect DNA damage and to initiate signal transduction cascades that employ Chk1 and Chk2 Ser/Thr kinases and Cdc25 phosphatases. The signal transducers activate p53 and inactivate cyclin-dependent kinases to inhibit cell cycle progression from G1 to $S$ (the G1/S checkpoint), DNA replication (the intra-S checkpoint), or G2 to mitosis (the G2/M checkpoint) (Sancar A. et al, 2004). The up-regulation of NKG2D ligand induced by genotoxic stress was prevented by pharmacological or genetic inhibition of ATR, ATM, or Chk1, indicating that up-regulation of NKG2D ligands is a consequence of DNA damage response (Gasser S. et al, 2005). Induction of DNA damage leads to p53 activation. The role of p53 in the up-regulation of NKG2D ligands was addressed by Textor and colleagues. They found that induction of wild-type p53, but not mutant p53, strongly up-regulated mRNA and cell surface expression of ULBP1 and ULBP2, and that the intronic p53 responsive elements in these two novel p53 target genes are responsible for the upregulation of ULBP1 and ULBP2 (Textor S. et al, 2011). The biological and medical implications of these findings have been addressed by several groups. Soriani and colleagues demonstrated that treatment with low doses of therapeutic agents such as doxorubicin, melphalan, and bortezomib commonly used in the management of patients with multiple myeloma leads to up-regulation of NKG2D ligands, and that the druginduced expression of NKG2D ligands was abolished after treatment with the ATM and ATR pharmacologic inhibitors (Soriani A. et al, 2009). We showed that treatment with 5Aza-2'-deoxycytidine (5-aza-dC), a DNA methyltransferase inhibitor, induces DNA 
damage-dependant up-regulation of NKG2D ligands (Tang KF. et al, 2008a). Cerboni and colleagues demonstrated that in response to superantigen, alloantigen, or a specific antigenic peptide, the expression of NKG2D ligands on the surface of $\mathrm{T}$ lymphocytes is induced, and that the induction of NKG2D ligand expression is the consequence of DNA damage (Cerboni C. et al, 2007). In addition, they demonstrated that activated $\mathrm{T}$ cells became susceptible to autologous NK lysis via NKG2D/NKG2DLs interaction and granule exocytosis, suggesting that NK lysis of T lymphocytes via NKG2D may be one of the mechanisms limiting T-cell responses (Cerboni C. et al, 2007). HIV up-regulates cell-surface expression of NKG2D ligands, including ULBP1, ULBP2, and ULBP3, but not MICA or MICB, in infected cells both in vitro and in vivo. HIV-1-induced up-regulation of NKG2D ligands contributes to HIV-1induced CD4 ${ }^{+}$T-lymphocyte depletion. Recently, two groups demonstrated that the HIV-1 Vpr protein activates the DNA damage response, which specifically induces surface expression of ULBP1 and ULBP2 (Richard J. et al, 2010; Ward J. et al, 2009).

\section{Decreased Dicer expression elicits up-regulation of MICA and MICB}

The DNA damage pathway regulates expression of innate immune system ligands for the NKG2D receptor. Human NKG2D ligands are up-regulated by genotoxic stress and stalled DNA replication. Dicer knockdown elicits DNA damage in human cells. These observations prompted us to test whether NKG2D ligands were up-regulated in Dicer knockdown cells. Quantitative RT-PCR and flow cytometry revealed markedly increased levels of MICA and MICB mRNAs and proteins in Dicer knockdown cells compared with mock-transfected or control siRNA-transfected cells. In contrast, inhibiting the expression of Dicer did not significantly alter the levels of ULBP1, ULBP2, and ULBP3 mRNAs. Upregulation of MICA and MICB by Dicer knockdown is prevented by pharmacologic or genetic inhibition of DNA damage pathway components, including ATM, ATR, or Chk1. This finding suggests that up-regulation of MICA and MICB is the result of DNA damage response activated by Dicer knockdown. Dicer knockdown cells also exhibited greater sensitivity to lysis by NKL, a cell line derived from an aggressive form of human natural killer cell leukemia. Lysis was partially inhibited by anti-NKG2D antibody, which indicated that up-regulated NKG2D ligands make the cells more susceptible to lysis by NK cells. This result suggests that Dicer-deficient cells may be cleared by NK or other immune cells (Tang KF. et al, 2008b).

Although we have shown that up-regulation of MICA and MICB in Dicer knockdown cells is the result of DNA damage response activation, further studies are necessary to determine whether other mechanisms are also involved in the regulation of MICA and MICB in Dicer knockdown cells. Stern-Ginossar and colleagues reported that one of the human cytomegalovirus encoded miRNAs, hcmv-miR-UL112, specifically down-regulates MICB expression during viral infection, leading to decreased binding of NKG2D and reduced killing by NK cells (Stern-Ginossar N. et al, 2007). The homv-miR-UL112 binding site in the MICB 3'-untranslated region is conserved among different MICB alleles and a similar site exists in the MICA 3'-untranslated region, suggesting that these sites are targeted by cellular microRNAs (Stern-Ginossar N. et al, 2007). To test this hypothesis, Stern-Ginossar and colleagues expressed MICB with or without its $3^{\prime}$-UTR in primary human foreskin fibroblast (HFF) cells. MICB expression was much higher when it was expressed without its $3^{\prime}$-UTR. Fusion of the 3'-UTR of MICA to green fluorescent protein (GFP) also inhibited GFP 
expression. These results indicated that the 3'-UTRs of MICA and MICB inhibit expression of the corresponding proteins. Knockdown of Drosha, an enzyme essential for miRNA biogenesis (Lee Y. et al, 2003), relieved the inhibitory effects, suggesting that cellular microRNAs do indeed regulate MICA and MICB expression. Further studies demonstrated that miR-20a, miR-93, miR106b, miR-372, miR-373, and miR-520d are involved in the regulation of MICA and MICB expression (Stern-Ginossar N. et al, 2008). Yadav and colleagues reported that miR-520b acted on both the MICA 3 '-UTR and the promoter region, causing a decrease in the levels of the MICA transcript and protein. However, an antisense oligonucleotide inhibitor of miR-520b increased the expression of a reporter construct containing the MICA 3'-UTR (Yadav D. et al, 2009). Dicer is the key enzyme involved in miRNA biogenesis, and knockdown of Dicer reduces levels of miRNAs. Therefore, it is conceivable that reduced levels of miRNAs may contribute to the upregulation of MICA and MICB in Dicer knockdown cells.

Interferon-alpha promotes expression of MICA in tumor cells (Zhang C. et al, 2008). Some siRNAs are found to activate protein kinase R (PKR) and induce global up-regulation of interferon-stimulated genes (Marques JT. \& Williams BR., 2005; Sledz CA. et al, 2003). Because dsRNAs are natural substrates of Dicer, knockdown of Dicer may stabilize endogenous dsRNAs. Elevated levels of endogenous dsRNAs may activate the interferon pathway. Therefore, it seems possible that up-regulation of MICA and MICB is the consequence of nonspecific activation of the interferon pathway in Dicer knockdown cells. Our results indicated that the phosphorylation status of PKR and the expression of interferon-stimulated genes are not changed in Dicer knockdown cells compared to control cells (Tang KF. et al, 2008b). However, we cannot exclude the possibility that complete depletion of Dicer may yield levels of endogenous dsRNAs high enough to activate the interferon pathway, and eventually up-regulate the expression of MICA and MICB.

The expression of MICA and MICB is tightly correlated with cell proliferation status. Highly confluent HCT116 cells grown to quiescence contain small amounts of MICA and MICB mRNAs and display low MIC surface protein expression. In rapidly proliferating cells, MICA and MICB mRNAs and surface proteins are strongly induced (Venkataraman GM. et al, 2007). Knockout of Dicer in hepatocytes leads to increased cell proliferation (Sekine S. et al, 2009), and Dicer knockdown lung adenocarcinoma (LKR13) cells grow faster than control cells (Kumar MS. et al, 2007). Therefore, it is possible that upregulation of MICA and MICB is the consequence of increased cell proliferation induced by down-regulation of Dicer.

Further studies are necessary to elucidate why loss of Dicer leads to up-regulation of MICA and MICB. Some possible mechanisms, summarized in Figure 2, are as follows: (i) decreased Dicer expression elicits DNA damage, which in turn induces up-regulation of MICA and MICB; (ii) loss of Dicer impairs biogenesis of miRNAs, some miRNAs, such as miR-20a, miR-93, miR106b, miR-372, miR-373, miR-520 and miR-520d, can repress the expression of MICA and MICB transcriptionally and posttranscriptionally; (iii) loss of Dicer may result in increased cell proliferation, and increased proliferation induces the transcription of MICA and MICB; and (iv) loss of Dicer stabilizes endogenous dsRNAs, and increased levels of the dsRNAs activate the interferon pathway, which in turn induces the expression of MICA and MICB. 


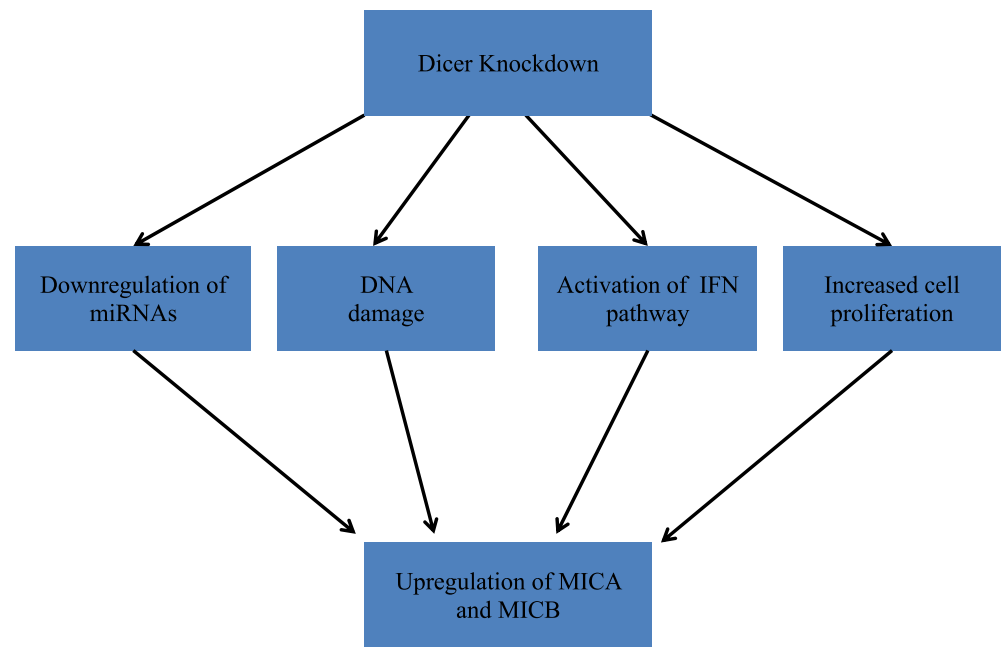

Fig. 2. Molecular mechanisms linking decreased Dicer expression to increased MICA and MICB expression

\section{Dicer, DNA damage, and tumorigenesis}

Compared with normal tissue, miRNAs are generally down-regulated in tumor tissue ( $\mathrm{Lu} \mathrm{J}$. et al, 2005). Levels of Dicer mRNA and protein are decreased in $60 \%$ of ovarian-cancer specimens. Low Dicer expression is significantly associated with advanced tumor stage and poor prediagnosis (Merritt WM. et al, 2008). We found that compared to the adjacent noncancerous liver tissues, Dicer mRNA and protein are reduced in hepatocellular carcinoma tissues in 34 of 36 patients (Wu JF. et al, 2011). Signs of a DNA damage response, including histone H2AX and Chk2 phosphorylation, p53 accumulation, focal staining of p53 binding protein 1 , are widely found in clinical specimens from different stages of human tumors and precancerous lesions, but not in normal tissues (Bartkova J. et al, 2005, 2006; DiTullio RA Jr. et al, 2002; Gorgoulis VG. et al, 2005). Decreased Dicer expression elicits DNA damage (Mudhasani R. et al, 2008; Peng JC. \& Karpen GH., 2009; Tang KF. et al, 2008b). Therefore, the following questions are intriguing: Is there an association between DNA damage and Dicer down-regulation in cancer tissues? If the answer is yes, what is the causal relationship between DNA damage and Dicer down-regulation in the process of carcinogenesis? What is the role of Dicer in carcinogenesis?

Kumar and colleagues found that loss of Dicer promotes tumorigenesis (Kumar MS. et al, 2007). They showed that Dicer knockdown cancer cells had a more pronounced transformed phenotype. In animals, Dicer knockdown cells formed tumors with accelerated growth; the tumors were also more invasive than control tumors. Furthermore, conditional deletion of Dicer enhanced tumor development in a K-Ras-induced mouse model of lung cancer (Kumar MS. et al, 2007). Sekine and colleagues disrupted Dicer in hepatocytes using a conditional knockout mouse model and found that Dicer elimination induces hepatocyte proliferation and overwhelming apoptosis. Unexpectedly, they found that two-thirds of the mutant mice spontaneously developed hepatocellular carcinomas (HCCs) at 1 year of age. The fact that the majority of Dicer deficient hepatocytes undergo apoptosis and that only a 
minor subset of Dicer-deficient hepatocytes gives rise to HCCs suggests the requirement of a "second hit" that promotes hepatocarcinogenesis in Dicer-deficient hepatocytes (Sekine S. et al, 2009). Based on these observations, I propose a simple model to explain how Dicer knockout leads to hepatocarinogenesis (Figure 3). Dicer depletion induces DNA damage via the mechanisms described in Figure 1, and DNA damage response leads to cell apoptosis or senescence. DNA damage may also result in DNA mutation such that cells containing oncogenic mutations may escape from apoptosis and senescence, eventually forming cancer.

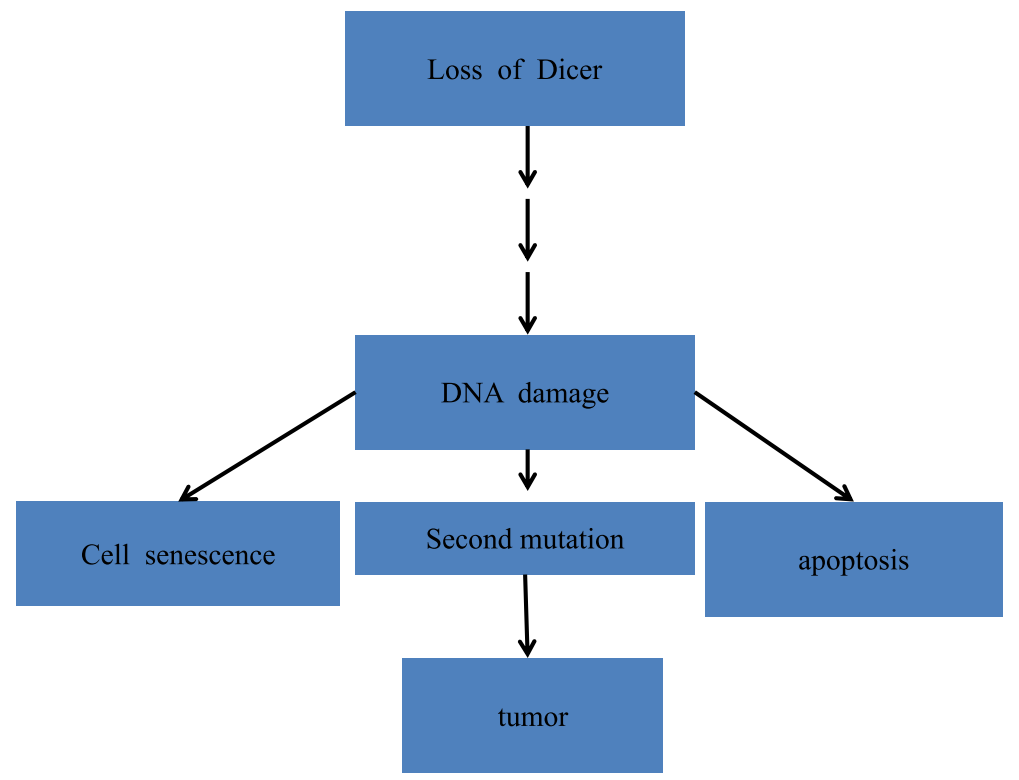

Fig. 3. Molecular mechanisms of Dicer knockout-induced tumorigenesis

Oncogene activation leads to augmented numbers of active DNA replicons and to alterations in DNA replication fork progression. These alterations activate DNA damage response, and eventually cell senescence or apoptosis. Genetic analyses indicate that early in tumorigenesis (before genomic instability and malignant conversion), human cells activate an ATR/ATM-regulated DNA damage response network that delays or prevents cancer. Mutations compromising this DNA damage response network might allow cell proliferation, survival, increased genomic instability and tumor progression (Bartkova J. et al, 2005, 2006; Di Micco R. et al, 2006).

Comparison of the mechanisms of oncogene-induced carcinogenesis (Figure 4) and Dicer depletion induced carcinogenesis suggests that Dicer is a tumor suppressor gene. However, Kumar and colleagues demonstrated that Dicer functions as a haploinsufficient tumor suppressor gene (Kumar MS. et al, 2009). Deletion of a single copy of Dicer in tumors from Dicerfl/+ animals reduced survival compared with controls. Moreover, tumors from Dicerfl/fl animals always maintained one functional Dicer allele; forced deletion of Dicer inhibited tumorigenesis. Analysis of human cancer genome copy number data reveals frequent deletion of Dicer. However, the gene has not been reported to undergo homozygous deletion (Kumar MS. et al, 2009). 


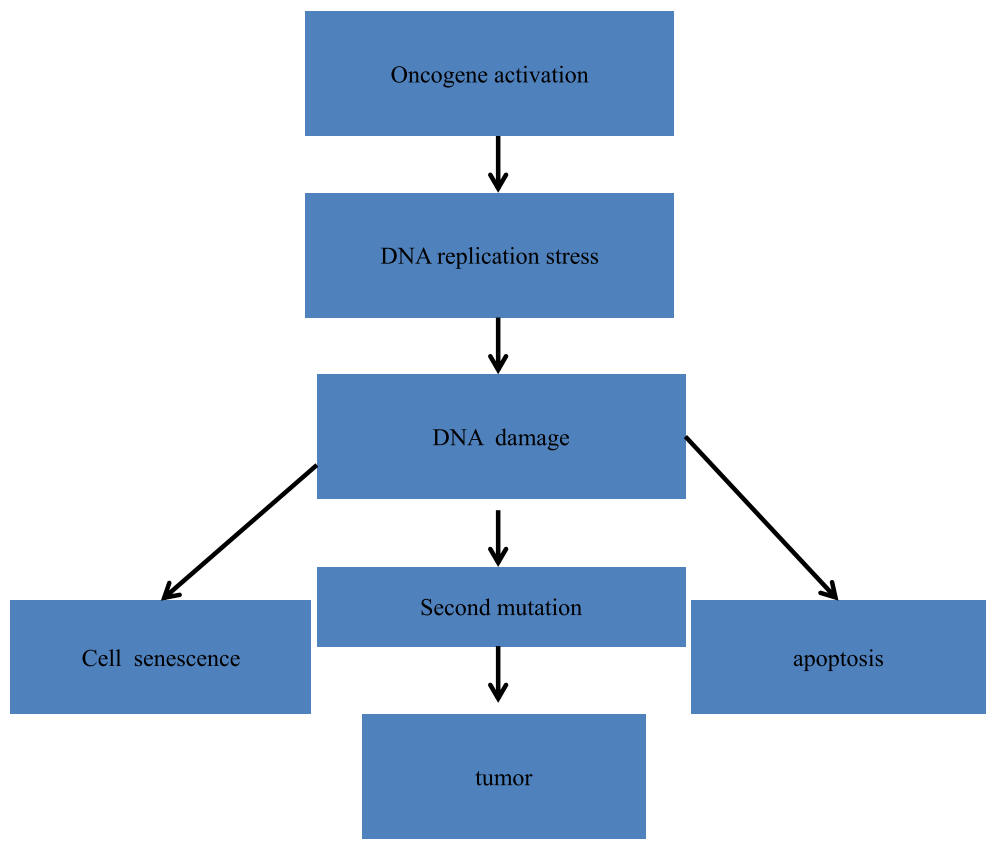

Fig. 4. Molecular mechanisms of oncogene-induced tumorigenesis

\section{MIC molecules, DNA damage and tumorigenesis}

Although evolved in parallel with the human MHC class I genes, MIC molecules (MICA and MICB) are quite different from MHC class I molecules. The characteristics of MIC molecules include the lack of association with beta-2-microglobulin, stable expression without conventional class I peptide ligands, and the absence of a CD8 binding site. The MIC genes are highly polymorphic. Around 60 alleles of MICA and 25 alleles of MICB have so far been identified (Bahram S. et al, 1994; Eagle RA. \& Trowsdale J., 2007;). T cells with variable region V-delta-1 gamma/delta T-cell receptors are distributed throughout the human intestinal epithelium and may function as sentinels that respond to selfantigens. MIC molecules are expressed on the surface of the intestinal epithelium cells, and are recognized by intestinal epithelial $\mathrm{T}$ cells expressing diverse V-delta-1 gamma/delta TCRs. These data suggest that MIC molecules may regulate the protective responses by the V-delta- 1 gamma/delta $\mathrm{T}$ cells in the epithelium of the intestinal tract (Groh V. et al, 1998). Cytomegalovirus (CMV) infection induces MIC expression and a concurrent down-regulation of MHC class I molecules on fibroblasts and endothelial cells (Groh V. et al, 2001). Functional analysis of T-cell cytotoxicity against CMV-infected fibroblasts showed that early after infection when MIC expression was low, antibodies to MHC class I, but not to MIC or NKG2D, could block T cell-mediated cytolysis (Groh V. et al, 2001). As MIC expression increased, antibody masking of MIC or NKG2D reduced target-cell lysis; anti-MHC class I antibodies further reduced cytolysis. This study suggests that MIC molecules are involved in the immune clearance of virus-infected cells (Groh V. et al, 2001). MICA binds NKG2D on gamma/delta T cells, CD8 ${ }^{+}$alpha/beta T 
cells, and natural killer cells. Engagement of NKG2D activates cytolytic responses of gamma/delta $\mathrm{T}$ cells and NK cells against transfectants and epithelial tumor cells expressing MICA (Bauer S. et al, 1999). These results indicate that MICA and MICB play important roles in anti-viral and anti-tumor immune response.

DNA damage response is activated in clinical specimens from different stages of human tumors and precancerous lesions, but not in normal tissues (Bartkova J. et al, 2005, 2006; DiTullio RA Jr. et al, 2002; Gorgoulis VG. et al, 2005). Activation of the DNA damage response results in cell cycle arrest, senescence, and apoptosis. It was proposed that tumor progression requires the appearance of mutations that misregulate the DNA damage response pathway, such as p53 mutations, which allay the cell cycle block and allow tumor outgrowth (Gasser S. \& Raulet DH., 2006; Halazonetis TD., 2004). DNA damage induces upregulation of NKG2D ligands (including MICA and MICB). Some components of the DNA damage checkpoints, including ATM and ATR (two proteins involved in DNA damage detection), and Chk1 (a protein that transduces the DNA damage signal to effector proteins), are essential for the up-regulation of NKG2D ligands (Gasser S. et al, 2005; Tang KF. et al, $2008 \mathrm{~b})$. p53 is one of the effector proteins of the DNA damage checkpoints, but is not required for up-regulation of NKG2D ligands, as indicated by DNA damage-induced expression of the ligands in p53-deficient cell lines (Gasser S. et al, 2005). The fact that other components of the DNA damage response, such as ATR and Chk1, are rarely mutated in tumors might explain why NKG2D ligands are frequently up-regulated in cancer cells (Gasser S. \& Raulet DH., 2006; Halazonetis TD., 2004). These findings suggest a possible role of the immune system, via the DNA damage response and NKG2D, in the elimination of precancerous cells and cancer cells.

In addition to promoting anti-tumor immune response, MICA and MICB can also suppress tumor immune surveillance. MICA associates with endoplasmic reticulum protein-5 (ERP5) on the surface of tumor cells, and the association is required for MICA shedding. Detailed analysis indicated that ERP5 and membrane-anchored MICA form transitory, mixed disulfide complexes, from which soluble MICA is released after proteolytic cleavage near the cell membrane. The secreted form of MIC molecules may bind to NKG2D receptor and inhibit the killing activity of effector cells (Kaiser BK. et al, 2007). NKG2D binding of MIC can induce endocytosis and degradation of NKG2D. In cancer patients, NKG2D expression was markedly reduced in both $\mathrm{CD}^{+}$tumor-infiltrating $\mathrm{T}$ cells and in peripheral blood $\mathrm{T}$ cells, and the reduction of NKG2D expression is associated with increased level of circulating tumor-derived soluble MICA. Down-regulation of NKG2D severely impairs the function of tumor antigen-specific effector T cells (Groh V. et al, 2002). MICA can also mediate strong suppressive effects on $\mathrm{T}$ cell proliferation. Responsiveness to MICAmediated suppression involves a receptor other than NKG2D. This finding might explain the observation that strong in vivo NKG2D ligand expression, such as in tumor cells, sometimes fails to support effective immune responses (Kriegeskorte AK. et al, 2005).

\section{Conclusion}

Dicer is misregulated in tumor tissues, and decreased Dicer expression induces the expression of MICA and MICB. MICA and MICB play important roles in anti-tumor immune response, and are frequently up-regulated in epithelial tumors of diverse tissue 
origins. These observations suggest that the intracellular immune system and the innate immune system have a good synergistic or additive effect in tumor immune surveillance. In addition, decreased Dicer expression elicits DNA damage, which in turn induces cell apoptosis and senescence. However, disruption of Dicer in hepatocytes promotes hepatocarcinogenesis. Therefore, the role and mechanism of Dicer in tumorigenesis need further investigation.

\section{Acknowledgment}

The author is supported by National Natural Science Foundation of China (grant Nos. 30700708, 30971621 \& 81171967), Zhejiang Provincial Natural Science Foundation of China (grant No. R2110503), Wenzhou Science and Technology Foundation of China (grant Nos. Y20100203), and the key project of Chongqing Medical Science Foundation (grant No. 09-1-17). The author wish to thank Dr. Gui-Ling Li for proof reading, Lu Lv and Yu-Xiao Fang for editing the reference.

\section{References}

Ayoub N, Jeyasekharan AD, Bernal JA, \& Venkitaraman AR.(2008). HP1-beta mobilization promotes chromatin changes that initiate the DNA damage response. Nature. (May 2008) , pp. 682-6, ISSN 0028-0836

Bahram S., Bresnahan M., Geraghty DE., \& Spies T. (1994). A second lineage of mammalian major histocompatibility complex class I genes.Proc Natl Acad Sci U S A, Vol. 91, No. 14,(Jul 1994), pp.6259-63,ISSN 0027-8424

Bartkova J., Horejsí Z., Koed K., Krämer A., Tort F., Zieger K., Guldberg P., Sehested M., Nesland JM., Lukas C., Ørntoft T., Lukas J., \& Bartek J. (2005).DNA damage response as a candidate anti-cancer barrier in early human tumorigenesis. Nature, Vol. 434, No. 7035,(Apr 2005), pp.864-70,ISSN 0028-0836

Bartkova J., Rezaei N., Liontos M., Karakaidos P., Kletsas D., Issaeva N., Vassiliou LV., Kolettas E., Niforou K., Zoumpourlis VC., Takaoka M., Nakagawa H., Tort F., Fugger K.,Johansson F., Sehested M., Andersen CL., Dyrskjot L., Ørntoft T., Lukas J., Kittas C., Helleday T., Halazonetis TD., Bartek J., \& Gorgoulis VG. (2006).Oncogene-induced senescence is part of the tumorigenesis barrier imposed by DNA damage checkpoints. Nature, Vol. 444, No. 7119,(Nov 2006), pp.633-7,ISSN 0028-0836

Bauer S., Groh V., Wu J., Steinle A., Phillips JH., Lanier LL., \& Spies T. (1999). Activation of NK cells and T cells by NKG2D, a receptor for stress-inducible MICA. Science, Vol. 285, No. 5428,(Jul 1999), pp.727-9,ISSN 0036-8075

Benetti R., Gonzalo S., Jaco I., Muñoz P., Gonzalez S., Schoeftner S., Murchison E., Andl T., Chen T., Klatt P., Li E., Serrano M., Millar S., Hannon G., \& Blasco MA. (2008).A mammalian microRNA cluster controls DNA methylation and telomere recombination via Rbl2-dependent regulation ofDNA methyltransferases. Nat Struct Mol Biol. Vol. 15, No. 9,( Sep 2008), pp.998,ISSN 1545-9985 
Bernstein E., Caudy AA., Hammond SM., \& Hannon GJ. (2001).Role for a bidentate ribonuclease in the initiation step of RNA interference. Nature. Vol. 409, No. 6818,(Jan 2001), pp.363-6,ISSN 0028-0836

Cerboni C., Zingoni A., Cippitelli M., Piccoli M., Frati L., \& Santoni A. (2007).Antigenactivated human $\mathrm{T}$ lymphocytes express cell-surface NKG2D ligands via an ATM/ATR-dependent mechanism and become susceptible to autologous NK-cell lysis. Blood. Vol. 110, No. 2,(July 2007), pp.606-15, ISSN 0006-4971

Cobb BS., Nesterova TB., Thompson E., Hertweck A., O'Connor E., Godwin J., Wilson CB., Brockdorff N., Fisher AG., Smale ST., \& Merkenschlager M. (2005).T cell lineage choice and differentiation in the absence of the RNase III enzyme Dicer. J Exp Med. Vol. 201, No. 9,(May 2005), pp.1367-73,ISSN 0022-1007

Cogoni C., Irelan JT., Schumacher M., Schmidhauser TJ., Selker EU., \& Macino G. (1996).Transgene silencing of the al-1 gene in vegetative cells of Neurospora is mediated by a cytoplasmic effector and does not depend on DNA-DNA interactions or DNA methylation. EMBO J. (Jun 1996), Vol. 15, No. 12,pp. 3153-63, ISSN 0261-4189

Czech B., Malone CD., Zhou R., Stark A., Schlingeheyde C., Dus M., Perrimon N., Kellis M., Wohlschlegel JA., Sachidanandam R., Hannon GJ., \& Brennecke J. (2008).An endogenous small interfering RNA pathway in Drosophila. Nature, Vol. 453, No. 7196,2008 Jun 5, pp.798-802. 22, ISSN 0028-0836

Kawamura Y, Saito K, Kin T, Ono Y, Asai K, Sunohara T, Okada TN, Siomi MC, \& Siomi H. (2008).Drosophila endogenous small RNAs bind to Argonaute 2 in somatic cells. Nature, Vol. 453, No. 7196,(Jun 2008), pp.793-7,ISSN 0028-0836

Di Micco R., Fumagalli M., Cicalese A., Piccinin S., Gasparini P., Luise C., Schurra C., Garre' M., Nuciforo PG., Bensimon A., Maestro R., Pelicci PG., \& d'Adda di Fagagna F. (2006). Oncogene-induced senescence is a DNA damage response triggered by DNA hyper-replication. Nature, Vol. 444, No. 7119,(Nov 2006), pp.638-42, ISSN 0028-0836

DiTullio RA Jr., Mochan TA., Venere M., Bartkova J., Sehested M., Bartek J., \& Halazonetis TD. (2002). 53BP1 functions in an ATM-dependent checkpoint pathway that is constitutively activated in human cancer. Nat Cell Biol, Vol.4, No.12, (Dec 2002), pp.998-1002, ISSN 1465-7392

Donaldson AD. (2005).Shaping time, chromatin structure and the DNA replication programme. Trends Genet, Vol.21, No.8, (Aug 2005), pp.444-9, ISSN 0168-9525

Eagle RA., \& Trowsdale J. (2007).Promiscuity and the single receptor, NKG2D. Nat Rev Immunol, Vol.7, No.9,( Sep 2007), pp.737-44, ISSN 1474-1733

Fire A., Albertson D., Harrison SW., \& Moerman DG. (1991).Production of antisense RNA leads to effective and specific inhibition of gene expression in C. elegans muscle. Development, Vol.113, No.2,( Oct 1991), pp.503-14, ISSN 0950-1991

Fire A., Xu S., Montgomery MK., Kostas SA., Driver SE., \& Mello CC. (1998). Potent and specific genetic interference by double-stranded RNA in Caenorhabditis elegans. Nature, Vol. 391, No. 6669,(Feb 1998), pp.806-11, ISSN 0028-0836 
Fire A. (2005).Nucleic acid structure and intracellular immunity, some recent ideas from the world of RNAi. Q Rev Biophys, Vol. 38, No. 4,( Nov 2005), pp.303-9,ISSN 00335835

Foster ER., \& Downs JA. (2005).Histone H2A phosphorylation in DNA double-strand break repair. FEBS J, Vol. 272, No. 13,( Jul 2005), pp.3231-40,ISSN 1742-464X

Gasior SL., Wakeman TP., Xu B., \& Deininger PL. (2006).The human LINE-1 retrotransposon creates DNA double-strand breaks. J Mol Biol, Vol. 357, No. 5,( Apr 2006), pp.138393,ISSN 0022-2836

Gasser S., Orsulic S., Brown EJ., \& Raulet DH. (2005).The DNA damage pathway regulates innate immune system ligands of the NKG2D receptor. Nature, Vol. 436, No. 7054,(Aug 2005), pp.1186-90,ISSN 0028-0836

Gasser S., \& Raulet DH. (2006).The DNA damage response arouses the immune system. Cancer Res, Vol. 66, No. 8,(Apr 2006), pp.3959-62, ISSN 0008-5472

Ghildiyal M., Seitz H., Horwich MD., Li C., Du T., Lee S., Xu J., Kittler EL., Zapp ML., Weng Z., \& Zamore PD. (2008).Endogenous siRNAs derived from transposons and mRNAs in Drosophila somatic cells. Science, Vol. 320, No. 5879,(May 2008), pp.1077-81,ISSN 0036-8075

Gorgoulis VG., Vassiliou LV., Karakaidos P., Zacharatos P., Kotsinas A., Liloglou T., Venere M., Ditullio RA Jr., Kastrinakis NG., Levy B., Kletsas D., Yoneta A., Herlyn M., Kittas C., \& Halazonetis TD. (2005).Activation of the DNA damage checkpoint and genomic instability in human precancerous lesions. Nature, Vol. 434, No. 7035,(Apr 2005), pp.907-13,ISSN 0028-0836

Grewal SI. (2010).RNAi-dependent formation of heterochromatin and its diverse functions. Curr Opin Genet Dev, Vol. 20, No. 2,(Apr 2010), pp.134-41,ISSN 0959-437X

Groh V., Rhinehart R., Randolph-Habecker J., Topp MS., Riddell SR., \& Spies T. (2001).Costimulation of CD8alphabeta T cells by NKG2D via engagement by MIC induced on virus-infected cells. Nat Immunol, Vol. 2, No. 3,(Mar 2001), pp.25560,ISSN 1529-2908

Groh V., Steinle A., Bauer S., \& Spies T. (1998). Recognition of stress-induced MHC molecules by intestinal epithelial gammadelta T cells. Science, Vol. 279, No. 5357,(Mar 1998), pp.1737-40, ISSN 0036-8075

Groh V., Wu J., Yee C., \& Spies T. (2002).Tumour-derived soluble MIC ligands impair expression of NKG2D and T-cell activation. Nature, Vol. 419, No. 6908,(Oct 2002), pp.734-8, ISSN 0028-0836

Guo S., \& Kemphues KJ. (1995).par-1, a gene required for establishing polarity in C. elegans embryos, encodes a putative Ser/Thr kinase that is asymmetrically distributed. Cell, Vol. 81, No. 4,( May 1995), pp.611-20, ISSN 0092-8674

Halazonetis TD. (2004). Constitutively active DNA damage checkpoint pathways as the driving force for the high frequency of 553 mutations in human cancer. DNA Repair (Amst), Vol. 3, No. 8-9,( Aug-Sep 2004), pp.1057-62,ISSN 1568-7864

Hamilton AJ., \& Baulcombe DC. (1999). A species of small antisense RNA in posttranscriptional gene silencing in plants. Science, Vol. 286, No. 5441,(Oct 1999), pp.950-2,ISSN 0036-8075 
Hammond SM., Bernstein E., Beach D., \& Hannon GJ. (2000).An RNA-directed nuclease mediates post-transcriptional gene silencing in Drosophila cells. Nature, Vol. 404, No. 6775,(Mar 2000), pp.293-6, ISSN 0028-0836

Hutvágner G, McLachlan J, Pasquinelli AE, Bálint E, Tuschl T, \& Zamore PD. (2001). A cellular function for the RNA-interference enzyme Dicer in the maturation of the let-7 small temporal RNA. Science, Vol. 293, No. 5531,(Aug 2001), pp.834-8, ISSN 0036-8075

Izant JG., \& Weintraub H. (1984).Inhibition of thymidine kinase gene expression by antisense RNA, molecular approach to genetic analysis. Cell, Vol. 36, No. 4,(Apr 1984), pp.1007-15,ISSN 0092-8674

Jing Q., Huang S., Guth S., Zarubin T., Motoyama A., Chen J., Di Padova F., Lin SC., Gram H., \& Han J. (2005).Involvement of microRNA in AU-rich element-mediated mRNA instability. Cell, Vol. 120, No. 5,(Mar 2005), pp.623-34,ISSN 0092-8674

Jørgensen HF., Azuara V., Amoils S., Spivakov M., Terry A., Nesterova T., Cobb BS., Ramsahoye B., Merkenschlager M., \& Fisher AG. (2007).The impact of chromatin modifiers on the timing of locus replication in mouse embryonic stem cells. Genome Biol, Vol.8, No.8,(2007), pp.R169,ISSN 1474-7596

Kaiser BK., Yim D., Chow IT., Gonzalez S., Dai Z., Mann HH., Strong RK., Groh V., \& Spies T. (2007). Disulphide-isomerase-enabled shedding of tumour-associated NKG2D ligands. Nature, Vol. 447, No. 7143,(May 2007), pp.482-6,ISSN 0028-0836

Kanellopoulou C., Muljo SA., Kung AL., Ganesan S., Drapkin R., Jenuwein T., Livingston DM., \& Rajewsky K. (2005).Dicer-deficient mouse embryonic stem cells are defective in differentiation and centromeric silencing. Genes Dev, Vol. 19, No. 4, (Feb 2005), pp.489-501,ISSN 0890-9369

Kriegeskorte AK., Gebhardt FE., Porcellini S., Schiemann M., Stemberger C., Franz TJ., Huster KM., Carayannopoulos LN., Yokoyama WM., Colonna M., Siccardi AG., Bauer S., \& Busch DH. (2005).NKG2D-independent suppression of $\mathrm{T}$ cell proliferation by H60 and MICA. Proc Natl Acad Sci U S A, Vol. 102, No. 33,(Aug 2005), pp.11805-10,ISSN 0027-8424

Kumar MS., Lu J., Mercer KL., Golub TR., \& Jacks T. (2007).Impaired microRNA processing enhances cellular transformation and tumorigenesis. Nat Genet, Vol. 39, No. 5,(May 2007), pp.673-7,ISSN 1061-4036

Kumar MS., Pester RE., Chen CY., Lane K., Chin C., Lu J., Kirsch DG., Golub TR., \& Jacks T. (2009). Dicer1 functions as a haploinsufficient tumor suppressor. Genes Dev, Vol. 23, No. 23,(Dec 2009), pp.2700-4,ISSN 0890-9369

Lanier LL. (2008). Up on the tightrope, natural killer cell activation and inhibition. Nat Immunol, Vol. 9, No. 5,(May 2008), pp.495-502,ISSN 1529-2908

Lee Y., Ahn C., Han J., Choi H., Kim J., Yim J., Lee J., Provost P., Rådmark O., Kim S., \& Kim VN. (2003).The nuclear RNase III Drosha initiates microRNA processing. Nature, Vol. 425, No. 6956,(Sep 2003), pp.415-9, ISSN 0028-0836

Lejeune E., \& Allshire RC. (2011).Common ground, small RNA programming and chromatin modifications. Curr Opin Cell Biol, Vol. 23, No. 3,(Jun 2011), pp.258-65, ISSN 0955-0674 
Lindbo JA., \& Dougherty WG. (1992).Untranslatable transcripts of the tobacco etch virus coat protein gene sequence can interfere with tobacco etch virus replication in transgenic plants and protoplasts. Virology, Vol. 189, No. 2,(Aug 1992), pp.725-33, ISSN 0042-6822

Lu J., Getz G., Miska EA., Alvarez-Saavedra E., Lamb J., Peck D., Sweet-Cordero A., Ebert BL., Mak RH., Ferrando AA., Downing JR., Jacks T., Horvitz HR., \& Golub TR. (2005).MicroRNA expression profiles classify human cancers. Nature, Vol. 435, No. 7043,(Jun 2005), pp.834-8,ISSN 0028-0836

Marques JT., \& Williams BR. (2005).Activation of the mammalian immune system by siRNAs. Nat Biotechnol, Vol. 23, No. 11,(Nov 2005), pp.1399-405,ISSN 1087-0156

Martienssen RA., Kloc A., Slotkin RK., \& Tanurdzić M. (2008).Epigenetic inheritance and reprogramming in plants and fission yeast. Cold Spring Harb Symp Quant Biol, (2008), pp.265-71,ISSN 0091-7451

Merritt WM., Lin YG., Han LY., Kamat AA., Spannuth WA., Schmandt R., Urbauer D., Pennacchio LA., Cheng JF., Nick AM., Deavers MT., Mourad-Zeidan A., Wang H., Mueller P,Lenburg ME., Gray JW., Mok S., Birrer MJ., Lopez-Berestein G., Coleman RL., Bar-Eli M., \& Sood AK. (2008).Dicer, Drosha, and outcomes in patients with ovarian cancer. N Engl J Med, Vol. 359, No. 25,(Dec 2008), pp.264150,ISSN 0028-4793

Mudhasani R., Zhu Z., Hutvagner G., Eischen CM., Lyle S., Hall LL., Lawrence JB., Imbalzano AN., \& Jones SN. (2008).Loss of miRNA biogenesis induces p19Arf-p53 signaling and senescence in primary cells. J Cell Biol, Vol. 181, No. 7,(2008 Jun), pp.1055-63,ISSN 0021-9525

Murchison EP., Partridge JF., Tam OH., Cheloufi S., \& Hannon GJ. (2005).Characterization of Dicer-deficient murine embryonic stem cells. Proc Natl Acad Sci U S A, Vol. 102, No. 34,(Aug 2005), pp.12135-40,ISSN 0036-8075

Nakagawa A., Shi Y., Kage-Nakadai E., Mitani S., \& Xue D. (2010).Caspase-dependent conversion of Dicer ribonuclease into a death-promoting deoxyribonuclease. Science, Vol. 328, No.5976,(Apr 2010), pp.327-34,ISSN 0036-8075

Napoli C., Lemieux C., \& Jorgensen R. (2007).Introduction of a Chimeric Chalcone Synthase Gene into Petunia Results in Reversible Co-Suppression of Homologous Genes in trans. Plant Cell, Vol.2, No.4,( Apr 1990) ,pp. 279-289, ISSN 1040-4651

Nellen W., \& Lichtenstein C. (1993).What makes an mRNA anti-sense-itive? Trends Biochem Sci, Vol. 18, No. 11,( Nov 1993), pp.419-23,ISSN 0036-8075

Okamura K., Chung WJ., Ruby JG., Guo H., Bartel DP., \& Lai EC. (2008).The Drosophila hairpin RNA pathway generates endogenous short interfering RNAs. Nature, Vol. 453, No. 7196,(Jun 2008), pp.803-6,ISSN 0028-0836

Peng JC., \& Karpen GH. (2007).H3K9 methylation and RNA interference regulate nucleolar organization and repeated DNA stability. Nat Cell Biol. Vol. 9, No.1,(Jan 2007), pp.25-35,ISSN 1465-7392

Peng JC., \& Karpen GH. (2008).Epigenetic regulation of heterochromatic DNA stability. Curr Opin Genet Dev, Vol. 18, No. 2,(Apr 2008), pp.204-11,ISSN 0959-437X 
Peng JC., \& Karpen GH. (2009).Heterochromatic genome stability requires regulators of histone H3 K9 methylation.PLoS Genet, Vol. 5, No. 3, (Mar 2009), pp.e1000435,ISSN 1553-7390

Plasterk RH. (2002).RNA silencing, the genome's immune system. Science, Vol. 296, No. 5571,(May 2002), pp.1263-5,ISSN 0036-8075

Richard J., Sindhu S., Pham TN., Belzile JP., \& Cohen EA. (2010). HIV-1 Vpr up-regulates expression of ligands for the activating NKG2D receptor and promotes NK cellmediated killing. Blood, Vol. 115, No. 7,( Feb 2010), pp.1354-63,ISSN 0006-4971

Riddle NC., \& Elgin SC. (2008).A role for RNAi in heterochromatin formation in Drosophila. Curr Top Microbiol Immunol, Vol. 320,(2008) , pp.185-209,ISSN 0070-217X

Sancar A, Lindsey-Boltz LA, Unsal-Kaçmaz K., \& Linn S. (2004).Molecular mechanisms of mammalian DNA repair and the DNA damage checkpoints. Annu Rev Biochem, Vol. 73 (Volume publication date July 2004), (July 2004), pp.39-85,ISSN 0066-4154

Sekine S., Ogawa R., Ito R., Hiraoka N., McManus MT., Kanai Y., \& Hebrok M. (2009).Disruption of Dicer1 induces dysregulated fetal gene expression and promotes hepatocarcinogenesis. Gastroenterology, Vol. 136, No. 7,( Jun 2009), pp.2304-2315.e1-4,ISSN 0016-5085

Sinkkonen L., Hugenschmidt T., Berninger P., Gaidatzis D., Mohn F., Artus-Revel CG., Zavolan M., Svoboda P., \& Filipowicz W. (2008).MicroRNAs control de novo DNA methylation through regulation of transcriptional repressors in mouse embryonic stemcells. Nat Struct Mol Biol, Vol. 15, No. 3,(Mar 2008), pp.259-67, ISSN 1545-9985

Sledz CA., Holko M., de Veer MJ., Silverman RH., \& Williams BR. (2003). Activation of the interferon system by short-interfering RNAs. Nat Cell Biol, Vol. 5, No. 9,(Sep 2003), pp.834-9,ISSN 1465-7392

Soriani A., Zingoni A., Cerboni C., Iannitto ML., Ricciardi MR., Di Gialleonardo V., Cippitelli M., Fionda C., Petrucci MT., Guarini A., Foà R., \& Santoni A. (2009). ATM-ATR-dependent up-regulation of DNAM-1 and NKG2D ligands on multiple myeloma cells by therapeutic agents resultsin enhanced NK-cell susceptibility and is associated with a senescent phenotype. Blood, Vol. 113, No. 15,( Apr 2009), pp.3503-11,ISSN 0006-4971

Stern-Ginossar N., Elefant N., Zimmermann A., Wolf DG., Saleh N., Biton M., Horwitz E., Prokocimer Z., Prichard M., Hahn G., Goldman-Wohl D., Greenfield C., Yagel S., Hengel H., Altuvia Y., Margalit H., \& Mandelboim O. (2007).Host immune system gene targeting by a viral miRNA. Science, Vol. 317, No. 5836,(Jul 2007), pp.37681,ISSN 0036-8075

Stern-Ginossar N., Gur C., Biton M., Horwitz E., Elboim M., Stanietsky N., Mandelboim M., \& Mandelboim O. (2008). Human microRNAs regulate stress-induced immune responses mediated by the receptor NKG2D. Nat Immunol, Vol.9, No.9,(Sep 2008), pp.1065-73,ISSN 1529-2908

Stern-Ginossar N., \& Mandelboim O. (2009).An integrated view of the regulation of NKG2D ligands. Immunology, Vol. 128, No.1,(Sep 2009), pp.1-6,ISSN 0019-2805

Tam OH., Aravin AA., Stein P., Girard A., Murchison EP., Cheloufi S., Hodges E., Anger M., Sachidanandam R., Schultz RM., \& Hannon GJ. (2008).Pseudogene-derived small 
interfering RNAs regulate gene expression in mouse oocytes. Nature, Vol. 453, No. 7194, (May 2008), pp.534-8,ISSN 0028-0836

Tang KF., He CX., Zeng GL., Wu J., Song GB., Shi YS., Zhang WG., Huang AL., Steinle A., \& Ren H. (2008a). Induction of MHC class I-related chain B (MICB) by 5-aza-2'deoxycytidine. Biochem Biophys Res Commun, Vol. 370, No. 4,(Jun 2008), pp.57883,ISSN 0006-291X

Tang KF., Ren H., Cao J., Zeng GL., Xie J., Chen M., Wang L., \& He CX. (2008b).Decreased Dicer expression elicits DNA damage and up-regulation of MICA and MICB. J Cell Biol, Vol. 182, No. 2,(Jul 2008), pp.233-9,ISSN 0021-9525

Textor S., Fiegler N., Arnold A., Porgador A., Hofmann TG., \& Cerwenka A. (2011).Human NK cells are alerted to induction of p53 in cancer cells by upregulation of the NKG2D ligands ULBP1 and ULBP2. Cancer Res, [Epub ahead of print] (Sep 2011). ISSN 0008-5472

Umbach JL., \& Cullen BR. (2009).The role of RNAi and microRNAs in animal virus replication and antiviral immunity. Genes Dev, Vol. 23, No. 10,(May 2009), pp.115164,ISSN 0890-9369

van der Krol AR., Mur LA., Beld M., Mol JN., \& Stuitje AR. (1990). Flavonoid genes in petunia, addition of a limited number of gene copies may lead to a suppression of gene expression. Plant Cell, Vol.2, No.4,( Apr 1990), pp.291-9,ISSN 1040-4651

Venkataraman GM., Suciu D., Groh V., Boss JM., \& Spies T. (2007).Promoter region architecture and transcriptional regulation of the genes for the MHC class I-related chain A and B ligands of NKG2D. J Immunol, Vol. 178, No. 2,(Jan 2007), pp.9619,ISSN 0022-1767

Verdel A., Jia S., Gerber S., Sugiyama T., Gygi S., Grewal SI., \& Moazed D. (2004).RNAimediated targeting of heterochromatin by the RITS complex. Science, Vol. 303, No. 5658,(Jan 2004), pp.672-6,ISSN 0036-8075

Volpe TA., Kidner C., Hall IM., Teng G., Grewal SI , \& Martienssen RA. (2002). Regulation of heterochromatic silencing and histone H3 lysine- 9 methylation by RNAi. Science, Vol. 297, No. 5588,(Sep 2002), pp.1833-7,ISSN 0036-8075

Ward J., Davis Z., DeHart J., Zimmerman E., Bosque A., Brunetta E., Mavilio D., Planelles V., \& Barker E. (2009).HIV-1 Vpr triggers natural killer cell-mediated lysis of infected cells through activation of the ATR-mediated DNA damageresponse. PLoS Pathog, Vol. 5, No. 10,(Oct 2009), pp.e1000613,ISSN 1553-7366

Watanabe T, Totoki Y, Toyoda A, Kaneda M, Kuramochi-Miyagawa S, Obata Y, Chiba H, Kohara Y, Kono T., Nakano T., Surani MA., Sakaki Y., \& Sasaki H. (2008).Endogenous siRNAs from naturally formed dsRNAs regulate transcripts in mouse oocytes. Nature, Vol. 453, No. 7194, (May 2008), 539-43, ISSN 0028-0836

Wu JF., Shen W., Liu NZ., Zeng GL., Yang M., Zuo GQ., Gan XN., Ren H., \& Tang KF. (2011).Down-regulation of Dicer in hepatocellular carcinoma. Med Oncol, Vol. 28, No. 3,(Sep 2011), pp.804-9,ISSN 1357-0560

Wu-Scharf D., Jeong B., Zhang C., \& Cerutti H. (2000).Transgene and transposon silencing in Chlamydomonas reinhardtii by a DEAH-box RNA helicase. Science, Vol. 290, No. 5494,(Nov 2000), pp.1159-62,ISSN 0036-8075 
Yadav D., Ngolab J., Lim RS., Krishnamurthy S., \& Bui JD. (2009).Cutting edge, downregulation of MHC class I-related chain A on tumor cells by IFN-gamma-induced microRNA. J Immunol, Vol. 182, No. 1,(Jan 2009), pp.39-43,ISSN 0022-1767

Zamore PD., Tuschl T., Sharp PA., \& Bartel DP. (2000).RNAi, double-stranded RNA directs the ATP-dependent cleavage of mRNA at 21 to 23 nucleotide intervals. Cell, Vol. 101, No. 1, (Mar 2000), pp.25-33,ISSN 0092-8674

Zhang C., Niu J., Zhang J., Wang Y., Zhou Z., Zhang J., \& Tian Z. (2008). Opposing effects of interferon-alpha and interferon-gamma on the expression of major histocompatibility complex class I chain-related A in tumors. Cancer Sci, Vol. 99, No. 6,( Jun 2008), pp.1279-86,ISSN 1347-9032

Zou Y., Liu Y., Wu X., \& Shell SM. (2006). Functions of human replication protein A (RPA), from DNA replication to DNA damage and stress responses. J Cell Physiol, Vol. 208, No. 2,(Aug 2006), pp.267-73,ISSN 0021-9541 


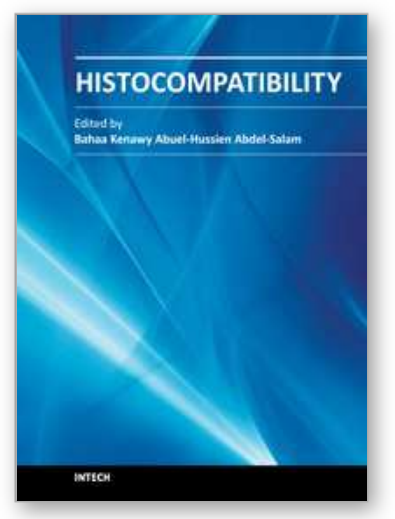

\author{
Histocompatibility \\ Edited by Dr. Bahaa Abdel-Salam
}

ISBN 978-953-51-0589-3

Hard cover, 188 pages

Publisher InTech

Published online 02, May, 2012

Published in print edition May, 2012

This book presents some recent researches related to histocompatibility for scientists interested in this field. It includes 10 chapters, in different topics, prepared by Sundararajulu Panneerchelvam and Mohd Nor Norazmi; Giada Amodio and Silvia Gregori; Adema Ribic; Bahaa K. A. Abdel-Salam; Kai-Fu Tang; Roberto Biassoni, Irene Vanni and Elisabetta Ugolotti; Wei-Cheng Yang, Lien-Siang Chou and Jer-Ming Hu; Shatrah Othman and Rohana Yusof; Masahiro Hirayama, Eiichi Azuma and Yoshihiro Komada; Gustav Roder, Linda Geironson, Elna Follin, Camilla Thuring and Kajsa Paulsson.

\title{
How to reference
}

In order to correctly reference this scholarly work, feel free to copy and paste the following:

Kai-Fu Tang (2012). Dicer Regulates the Expression of Major Histocompatibility Complex (MHC) Class I Chain-Related Genes A and B, Histocompatibility, Dr. Bahaa Abdel-Salam (Ed.), ISBN: 978-953-51-0589-3, InTech, Available from: http://www.intechopen.com/books/histocompatibility/dicer-regulates-the-expression-ofmajor-histocompatibility-complex-mhc-class-i-chain-related-genes-a

\section{INTECH}

open science | open minds

\section{InTech Europe}

University Campus STeP Ri

Slavka Krautzeka 83/A

51000 Rijeka, Croatia

Phone: +385 (51) 770447

Fax: +385 (51) 686166

www.intechopen.com

\section{InTech China}

Unit 405, Office Block, Hotel Equatorial Shanghai

No.65, Yan An Road (West), Shanghai, 200040, China

中国上海市延安西路65号上海国际贵都大饭店办公楼405单元

Phone: +86-21-62489820

Fax: +86-21-62489821 
(C) 2012 The Author(s). Licensee IntechOpen. This is an open access article distributed under the terms of the Creative Commons Attribution 3.0 License, which permits unrestricted use, distribution, and reproduction in any medium, provided the original work is properly cited. 